\title{
Penggunaan Media Peta Konsep Melalui Metode Bermain Peran
}

\author{
Siti Yantimala \\ SMPN 2 Trowulan \\ Email: sitiyantimala@gmail.com
}

\begin{abstract}
Abstrak
Penelitian bertujuan meningkatkan hasil belajar IPS dengan menggunakan media peta konsep melalui Metode Bermain Peran pada siswa SMP. Subyek penelitian adalah siswa kelas VII A SMP Negeri 2 Trowulan yang berjumlah 31 siswa. Setiap tahap dalam penelitian dilakukan dengan partisipatif dan kolaboratif antar sesama guru Mapel IPS. Hasil penelitian menunjukkan adanya peningkatan hasil belajar siswa dari siklus pertama dan siklus kedua. Berdasarkan analisis hasil belajar siswa menunjukkan peningkatan yang signifikan dan sesuai dengan hasil yang diharapkan dalam tujuan pembelajaran.
\end{abstract}

Kata Kunci : hasil belajar IPS, Media Peta Konsep, Metode Bermain Peran

\section{PENDAHULUAN}

Ilmu Pengetahuan Sosial adalah mata pelajaran integrasi antara Sejarah, Ekonomi, Geografi, dan Sosiologi. Sehingga materi dalam mata pelajaran tersebut sangat luas dan yang harus ditempuh dalam waktu yang terbatas. Oleh karena itu seorang guru dituntut untuk menyajikan materi yang sistematis, komprehensif, dan terpadu

Oleh karena itu guru melalui mata pelajaran yang dibelajarkan pada siswa, harus dapat memberikan bekal tidak saja berupa pengetahuan, tetapi lebih dari itu juga yang menyangkut tentang nilai-nilai kemanusiaan (humanisme) sebagai bekal (modal) dalam menghadapi tantangan global, pengaruh negatif dari kemajuan iptek dan pembangunan. Pada konteks ini, pembelajaran IPS di sekolah memiliki tempat yang strategis dan penting. Hal ini mengingat, sebagaimana termuat dalam Peraturan Menteri Pendidikan Nasional (Permendiknas) Nomor 22 Tahun 2006 Tentang Standar Isi, bahwa melalui 
mata pelajaran IPS, peserta didik diarahkan untuk dapat menjadi warga negara Indonesia yang demokratis dan bertanggung jawab, serta warga dunia yang cinta damai.

Lebih lanjut, dengan merujuk pada Permendiknas tersebut, mata pelajaran IPS bertujuan agar siswa memiliki kemampuan sebagai berikut.

1.Mengenal konsep-konsep yang berkaitan dengan kehidupan masyarakat dan Lingkungannya

2.Memiliki kemampuan dasar untuk berpikir logis dan kritis, rasa ingin tahu, inkuiri, memecahkan masalah, dan keterampilan dalam kehidupan sosial 3.Memiliki komitmen dan kesadaran terhadap nilai-nilai sosial dan kemanusiaan 4.Memiliki kemampuan berkomunikasi, bekerjasama dan berkompetisi dalam masyarakat yang majemuk, di tingkat lokal, nasional, dan global

Pembelajaran Ilmu Pengetahuan Sosial bertujuan untuk memperssiapkan siswa menjadi warga masyarakat baik scara akademik maupun social dalam menghadapi tantangan perkembangan zaman. Secara akademik, siswa dapat menguasai bidang kajian IPS secara sistematis, komprehensif, dan terpadu. Secara social. siswa diharapkan mampu berinteraksi dengan lingkungan sekitar dengan baik. Karena tantangan perkembangan zaman di masa datang akan semakin berat dengan masyarakat global yang mengalami perubahan setiap saat.

Dalam pembelajaran IPS di kelas merupakan miniature masyarakat yang sesungguhnya, sehingga siswa salah satu individu yang mewakili masyarakat sebenarnya. Dinamika masyarakat sangat beragam mempengaruhi pola perilaku di dalam kelas. Salah satunya kelas VII A memiliki karateristik siswa secara akademik kurang dan secara social sangat memprihatinkan. Hal ini dapat diketahui dari dokumen hasil prestasi belajar siswa,catatan pelanggaran di kelas maupun dalam administrasi BK.

Hasil pengamatan beberapa guru melalui diskusi, fenomena di kelas VII A sangat penting untuk dilakukan penelitian karena beberapa guru mengalami banyak kendala dalam menyampaikan materi. Karena metode pembelajaran kurang variatif dan cenderung monoton. Penggunaan media sebagai jembatan untuk mentransformasi materi belum sepenuhnya dilakukan. Sehingga siswa kurang memahami informasi dengan jelas akibatnya hasil ulangan harian kurang memuaskan, diberikan tugas oleh guru tidak dikerjakan dan keaktifan siswa rendah. Berdasarkan paparan tersebut di atas, maka peneliti ingin mencoba melakukan penelitian dengan judul "Upaya Meningkatkan 
Hasil Belajar IPSMenggunakan Media Peta Konsep Melalui Metode Pembelajaran Bermain Peran Pada Siswa

\section{METODE PENELITIAN}

Penelitian ini merupakan penelitian tindakan (action research), karena penelitian dilakukan untuk memecahkan masalah pembelajaran di kelas. Penelitian ini juga termasuk penelitian deskriptif, sebab menggambarkan bagaimana suatu metode pembelajaran diterapkan dan bagaimana hasil yang diinginkan dapat dicapai.Penelitian ini mengacu pada perbaikan pembelajaran yang berkesinambungan. Kemmis dan Tagart (1988 :14) menyatakan bahwa model penelitian tindakan adalah berbentuk spiral. Tahapan penelitian tindakan pada suatu siklus meliputi perencanaan atau pelaksanaan observasi dan refleksi. Siklus ini berlanjut dan akan dihentikan jika sesuai dengan kebutuhan dan dirasa sudah cukup.

Sesuai dengan jenis penelitian yang dipilih, penelitian ini menggunakan model penelitian tindakan dari Kemmis dan Taggart (dalam Arikunto, Suharsimi, 2002: 83), yaitu berbentuk spiral dari siklus yang satu ke siklus yang berikutnya. Setiap siklus meliputi planning (rencana), action (tindakan), observation (pengamatan), dan reflection (refleksi). Langkah pada siklus berikutnya adalah perencanaan yang sudah direvisi, tindakan, pengamatan, dan refleksi. Sebelum masuk pada siklus I dilakukan tindakan pendahuluan yang berupa identifikasi permasalahan.

Subjek penelitian adalah siswa-siswi kelas VII A SMP Negeri 2 Trowulan Tahun Pelajaran 2015/2016 pada Kompetensi Dasar : 4.4 Mendeskripsikan gejala-gejala yang terjadi di atmosfer dan hidrosfer serta dampaknya terhadap kehidupan. Penelitian ini dilaksanakan mengingat karakteristik dan kondisi siswa kelas VII A SMP Negeri 2 Trowulan sangat heterogen. Berdasarkan buku perkembangan siswa bila diamati dari sisi karakteristik siswa antara lain ada yang super aktif, kurang percaya diri, kurang perhatian/ngobrol dengan temannya, pendiam, malu malu, kurang mampu berkomunikasi dengan temannya, bahkan ada cuek dan apatis saat pembelajaran. Dari sisi akademis siswa, berdasarkan Daftar Kumpulan Nilai Semester Ganjil terdapat kurang lebih $20 \%$ tergolong nilai tinggi, 30\% tergolong nilai sedang dan 50\% nilai rendah. Melihat karakteristik, kondisi dan nilai akademis siswa yang sedemikian tersebut peneliti berusaha mencari dan menemukan solusi agar perbedaan karakter dan 
konsisi siswa tersebut tidak menjadi sebab menurunnya hasil belajar siswa tetapi justru dapat dimanfaatkan / digunakan untuk meningkatkan hasil belajar siswa.

Data penelitian diperoleh dari data observasi berupa pengamatan perngelolaan metode pembelajaran bermain peran dan pengamatan aktivitas guru dan siswa pada setiap siklus.

Data lembar observasi diambil dari dua pengamatan yaitu data pengamatan pengelolaan metode pembelajaran bermain peran yang digunakan untuk mengetahui penerapan metode pembelajaran bermain perandalam meningkatkanhasil belajar siswa dan data pengamatan aktivitas guru dan siswa.

Data hasil tes produk, nilai tes bermain peran dan tes tulis untuk mengetahui peningkatan hasil belajar siswa setelah diterapkannya metode pembelajaran bermain peran

\section{HASIL DAN PEMBAHASAN}

Dari seluruh rangkaian kegiatan guru dan siswa dalam proses pembelajaran dari siklus I sampai siklus II memiliki perubahan yang cukup berarti dengan kata lain secara umum tujuan pembelajaran telah tercapai, yakni dari siklus II upaya pengembangan dan pengayaan materi ajar memberi dampak penguatan dan motivasi belajar siswa, sehingga siswa mampu menyelesaikan tugas-tugas serta siswa memperoleh nilai melebihi batas minimal ketuntasan.

Upaya peneliti dan pengamat dalam pelaksanaan telah memperlihatkan kemajuan yang cukup berarti, terlihat dari rata-rata kelas menunjukkan peningkatan dari pertemuan satu sampai ke pertemuan ketiga dari tiap siklusnya, terutama pada siklus II menunjukan keberhasilan hampir seluruh siswa memperoleh nilai baik diatas batas KKM.

Peneliti sudah berusaha dan berupaya menciptakan kondisi pembelajaran kearah keterlibatan siswa secara aktif. Siswa aktif dalam belajar seperti kegiatan tanya jawab saat melaksanakan tugas dan pembelajaran sehingga siswa terlihat lebih aktif, dan suasana kelompok belajar yang aktif mampu memecahkan masalah atau tugas yang diberikan peneliti.

Kegiatan pembelajaran menjadi lebih bermakna, terlihat adanya kegiatan aktivitas siwa lebih aktif dari siklus pertama atau siklus sebelumnya, baik kegiatan individu maupan kelompok. Sedangkan pembelajaran secara klasikal relatif kurang. Kondisi dan 
ruang kelas disusun sedemikian rupa sehingga memungkinkan siswa lebih aktif dan bisa bekerja bersama-sama terutama kegiatan kelompok.

Pemilihan pengunaan media peta konsep melalui metode pembelajaran bermain peranpada proses pembelajaran yang dipadukan dan divariasikan dengan metode dan model yang lainnya, benar-benar mampu menciptakan suasana pembelajaran yang lebih bermakna dan mampu menciptakan dan menghidupkan keaktifan siswa,

Strategi pembelajaran yang disusun oleh peneliti meliputi 3 tahap yakni kegiatan awal, kegiatan inti, dan kegiatan akhir serta tindak lanjut, seluruh indikator strategi pembelajaran merupakan satu kesatuan yang sistemik dan sistimatik. Strategi mengajar pada dasarnya adalah tindakan nyata dari guru atau praktik guru melaksanakan pengajaran melalui cara tertentu, yang dinilai lebih efektif dan lebih efisien. Dengan perkataan lain strategi mengajar adalah politik atau taktik yang digunakan guru dalam melaksanakan mengajar di kelas. Politik atau taktik tersebut hendaknya mencerminkan langkah-langkah secara sistemik dan sistematik. Sistemik mengandung pengertian bahwa setiap komponen belajar mengajar saling berkaitan satu sama lain sehingga terorganisasikan secara terpadu dalam mencapai tujuan. Sedangkan sistematik mengandung pengertian bahwa langkah-langkah yang dilakukan guru pada waktu mengajar berurutan secara rapi, dan logis sehingga mendukung tercapainya tujuan.

Suasana pembelajaran mendorong siswa lebih temotivasi dalam belajar adalah kemampuan guru dalam mengolola dan pemilihan model pembelajaran yang mampu membawa siswa lebih aktif dalam belajar, seperti pemilihan dan pendekatan penggunaan media peta konsep melalui metode pembelajaran bermain peran .

Siswa belajar karena didorong oleh kekuatan mentalnya, kekuatan mental itu berupa keinginan, perhatian, kemauan, atau cita-cita. Dorongan yang kuat dalam diri siswa sebagai peserta didik yang memiliki hasrat ingin memiliki satu perubahan kearah yang lebih maju merupakan bentuk motivasi belajar. Dalam motivasi terkandung adanya keinginan yang mengaktifkan, menggerakan, menyalurkan dan mengarahkan sikap dan perilaku individu belajar.

Pemilihan penggunaan media peta konsep melalui metode pembelajaran bermain peran pada penelitian mencoba melatih siswa memecahkan masalah, terbukti melalui penelitian dalam kegiatan kelompok belajar setiap siswa mampu bekerja sama secara aktif mulai dari menentukan masalah, mencari alternatif jawaban, melalui tanya jawab 
diantara anggota kelompok belajar, akhirnya siswa menemukan jawaban, membuat peta konsep, berani menampilkan peran, dan menentukan kesimpulan jawabannya bersamasama dari hasil keputusan bersama.

Berdasarkan hasil penelitian bahwa penggunaan media peta konsep melalui metode pembelajaran bermain peranmampu meningkatkan hasil belajar siswa sehingga mampu menciptakan kualitas pembelajaran terutama upaya meningkatkan penguasaan pada materi Hidrosfer di kelas VII-A Siswa SMPN 2 Trowulan Kecamatan Trowulan Kabupaten Mojokerto, dari hasil evaluasi siklus I sampai siklus II menunjukan hasil belajar dari sejumlah siswa 31 orang siswa, siklus I terbagi dua kali pertemuan pembelajaran dan siklus II terbagi dua kali pertemuan pembelajaran, rata-rata kelas menunjukan perolehan hasil belajar dalam satu kelas, tiap pertemuan sudah menghasilkan skor diatas nilai KKM yaitu 76. Pada siklus I dari 31 siswa ada 6 orang yang masih memperoleh nilai dibawah KKM, di siklus II menunjukkan $94 \%$ seluruh siswa tuntas dalam pembelajaran materi Hidrosfer.

Berdasarkan hasil refleksi dan hasil penelitian yang telah dilakukan, menunjukan pembelajaran dengan penggunaan media peta konsep melalui metode pembelajaran bermain peran yang diimplementasikan oleh peneliti dalam proses pembelajaran mampu meningkatkan hasil belajar siswa. Seiring dengan peningkatan kualitas pembelajaran yang dikembangkan oleh guru, peran serta siswa dalam belajarpun semakin meningkat. Keterampilan dan kemampuan siswa dalam memahami Hidrosfer semakin meningkat. Pembelajaran dengan menggunakan media peta konsep melalui metode pembelajaran bermain peran dapat meningkatkan hasil belajar siswa.

\section{KESIMPULAN}

Berdasarkan hasil penelitian yang telah dipaparkan selama dua siklus, hasil seluruh pembahasan serta analisis yang tela dilakukan dapat disimpulkan sebagai berikut, Penggunaan Media Peta Konsep melalui Metode Pembelajaran Bermain Peran mampu meningkatkan hasil belajar siswa seperti yang dilakukan oleh peneliti dalam penelitian tindakan kelas. Keberhasilan penggunaan peta secara signifikan dapat dilihat dari hasil evaluasi tiap siklusnya, menunjukan peningkatan dari $80 \%$ pada siklus I menjadi $90 \%$ pada siklus II. Berdasarkan hasil temuan-temuan dari penelitian beserta refleksi yang dilakukan dalam tindakan kelas di kelas VII-A SMPN 2 Trowulan Kecamatan Trowulan Kabupaten Mojokerto, maka peneliti menyampaikan saran-saran 
yang berkaitan pembelajaran,. Bagi guru kelas VII-A Sekolah Menengah Pertama, mengembangkan penggunaan media peta konsep melalui metode pembelajaran Bermain Peran dapat meningkatkan efektivitas dalam menyusun teknik dan strategi pembelajaran.serta dapat dijadikan model pendekatan (approach) dalam menyesuaikan kompetensi dasarnya, terutama kepada siswa kelas VII-A Sekolah Menengah Pertama.

Bagi para guru Sekolah menengah, diharapkan mampu melaksanakan penelitian tindakan kelas serta mampu mengembangkan metode-metode pembelajaran, termasuk metode pembelajaran bermain peran sebagai bentuk panggilan profesi seorang guru, karena model pembelajaran mampu meningkatkan kualitas dan efektivitas pembelajaran. Bagi Kepala Sekolah, dapat memberikan pembinaan dan mendorong para guru untuk melakukan penelitian tindakan kelas sebagai upaya meningkatkan kualitas pembelajaran. Bagi lembaga pendidikan atau pengembang pendidikan Sekolah menengah, diharapkan mampu meningkatkan kualitas pendidikannya yakni dengan memberikan pelatihan khusus bagi para guru dalam mengimplementasikan metode pembelajaran serta pelatihan penelitian tindakan kelas.

\section{DAFTAR PUSTAKA}

Arends, Richard I, 2008, Learning To Teach, Yogyakarta, Pustaka Pelajar.

Al Muchtar, Suwarna, 2001, Epistimologi Pendidikan Ilmu Pengetahuan Sosial, Bandung, Gelar Pustaka Mandiri.

Arikunto, Suharsimi, 2006, Prosedur Penelitian Suatu Pendekatan Praktek,Jakarta, PT Rineka Cipta.

Arikunto, Suharsimi, 2005, Manajemen Penelitian, Jakarta, PT Rineka Cipta.

Alwan Mahsul, 2009 tentang "Pengembangan Perangkat Pembelajaran Metode Bermain Peran yang Diajarkan dengan Model Pembelajaran Langsung Pada Pokok Bahasan Bumi dan Alam Semesta”, Tesis Magister Pendidikan, Universitas Negeri Surabaya.

B.Uno, Hamzah, 2006, Perencanaan Pembelajaran, Jakarta, Bumi Aksara

B.Uno, Hamzah, 2008, Model Pembelajaran yang Menciptakan Proses Belajar Mengajar yang Kreatif \& Efektif, Jakarta, Bumi Aksara.

Bahri Djamarah, Syaiful dan Aswan Zain, 2006, Strategi Belajar Mengajar, Jakarta, PT Rineka Cipta.

Creswell, W. John, 2010, Research Design Pendekatan Kualitatif, Kuantitatif dan Mixed, Yogjakarta, Pustaka Pelajar.

Emzir, 2010, Metodologi Penelitian Pendidikan Kuantitatif dan Kualitatif, Jakarta, PT Rajagrafindo Persada.

Hayat, Bahrul dan Suhendra Yusuf, 2010, Mutu Pendidikan, Jakarta, Bumi Aksara. 
Hiwa Wonda, 2009 tentang "Penerapan Model Pembelajaran Terpadu Tipe Connected untuk Meningkatkan Efektivitas Pembelajaran IPS Kelas IIV pada SD Inpres Oesapa Kecil 1 Kupang”, Tesis Magister Pendidikan, Universitas Negeri Surabaya.

Khoiru Ahmadi, Iif dan Sofan Amri, 2011, Mengembangkan Pembelajaran IPS Terpadu, Jakarta, Prestasi Pustaka Publsher.

Kasali, Rhenald, 2007, Re-code Your-Change- DNA, Jakarta, PT Gramedia Pustaka Utama.

Matthew H. Olson, Hergenhahn, 2009, Theories Of Learning (Teori Belajar), Jakarta, Kencana Prenada Media Group.

Mulyasa, 2007, Menjadi Guru Profesional, Bandung, PT Remaja Rosdakarya.

Muin Abd., 2012, tentang " Pengaruh Model Pembelajaran Masalah Sosial, Pembelajaran Langsung dan Motivasi Belajar Terhadap Peningkatan Berfikir Kritis dan Kepedulian Sosial Siswa”, Tesis Magister Pendidikan, Universitas Negeri Surabaya.

Media, 2012, Majalah Bulanan Dinas Pendidikan Provinsi Jawa Timur, Surabaya, CV Karunia.

Riyanto, Yatim, 2010, Paradigma Baru Pembelajaran, Jakarta, Kencana Prenada Media Group

Riduwan, 2010, Skala Pengukuran Variabel-variabel Peneltian, Bandung, Alfabeta.

Riduwan, Rusyana Adun, Enas, 2011, Cara Mudah Belajar SPSS 17.0 dan Aplikasi Statistik Penelitian, Bandung, CV. Alfabeta.

Sanjaya, Wina, 2007, Strategi Pembelajaran Berorientasi Standar Proses Pendidikan, Jakarta, Kencana Prenada Media Group.

Santrock, W. john, 2009, Psikologi Pendidikan educational psychology, Jakarta, Penerbit Salemba Humanika.

Santoso, Singgih, 2009, Panduan Lengkap Menguasai Statistik dengan SPSS 17, Jakarta, PT Elex Media Komputindo.

Silberman, Mel, 2009, Active Learning, Yogjakarta, Pustaka Insan Madani.

Sagala, Syaiful, 2009, Konsep dan Makna Pembelajaran, Bandung, Alfabeta.

Slavin, E. Robert, 2008, Psikologi Pendidikan teori dan praktek jilid 1, Jakarta, PT Indeks.

Slavin, E. Robert, 2008, Psikologi Pendidikan teori dan praktek jilid 2, Jakarta, PT Indeks.

Smith, Mark K., dkk, 2010, Teori Pembelajaran dan Pengajaran, Yogyakarta, Mirza Media Pustaka.

Sugiyono, 2010, Metode Penelitian Kuantitatif Kulaitatif dan RD, Bandung, Alfabeta.

Sunarya, Abas, Sudaryono, Asep Saefullah, 2011, Kewirausahaan, Yogyakarta, Penerbit Andi.

Suherman, Eman, 2008, Desain Pembelajaran Kewirusahaan, Bandung, Alfabeta.

Sunari, 2011 tentang "Pengembangan Perangkat Pembelajaran IPA Berorientasi Metode

Bermain Peran yang Diajarkan dengan Model Pembelajaran Kooperatif Tipe STAD di $S D$ ”, Tesis Magister Pendidikan, Universitas Negeri Surabaya.

Suyono, Haryanto, 2011, Belajar dan Pembelajaran teori dan konsep dasar, Surabaya, Unesa Pres dan Rosdajaya.

Solihatin, Etin dan Raharjo, 2007, Cooperative Learning Analisis Model Pembelajaran IPS, Jakarta, PT. Bumi Aksara. 
Trihendradi, C, 2009, 7 Langkah Mudah Melakukan Analisis Statistik Menggunakan SPSS 17, Yogjakarta, CV Andi Offset.

Umiarso dan Imam Gojali, 2010, Manajemen Mutu Sekolah di era Otonomi Pendidikan, Yogjakarta, IRGSod. 